\title{
CLASS CRYSTALLIZATION: WITHIN REACH OF INDUSTRIAL WORKERS IN INDIA?
}

\author{
GOPALAKRISHNAN KARUNANITHI ${ }^{1}$
}

\begin{abstract}
Over the years, mostly non-communist union leaders in industries have been encouraging their caste workers to become members of their unions first, and subsequently members of their caste associations. However, their interest in developing workers' class-consciousness is rather decreasing. In contrast, it is mainly communist union leaders who motivate the workers in their unions to defend their class interests through class action. Besides this, the management's strategy of recognizing, consulting and seeking the support of the numerical majority of non-communist union leaders and keeping their counterparts in the numerical minority of communist unions away from these activities is nothing but a policy of 'divide and rule' that impedes the formation of workers unity and ultimately leads them to confrontation through 'inter-union conflicts'. Moreover, external forces, especially some caste-based political parties, are keen on organizing their caste workers in unions affiliated to their parties in order to help them become union leaders which eventually results in 'intra-union conflicts'. Such conflicts thwart the development of workers' class-consciousness, thereby hindering the process of class crystallization.
\end{abstract}

KEYWORDS Labor Union, Caste, Class, Class-consciousness, Class Crystallization.

\section{INTRODUCTION}

Cotton spinning and weaving were important industries in Tamilnadu, a Southern State of India, in the first quarter of the 20th century. Because of this, the history of trade unions in this state largely dates back to the formation

1 Dr. Karunanithi is professor at the School of Social Sciences and Languages, VIT University, Vellore 632 014, Tamilnadu, India, e-mail: karunanithig@gmail.com This paper is based on a report from a project conducted during 1995-1998 with the financial support of the University Grants Commission, New Delhi. 
of Labor Organizations in the cotton spinning and weaving mills in 1940. In the state, almost all the mills are located in the cotton-growing districts such as Coimbatore, Marudai, Erode, Salem, Karur and Tirunelveli. Even before the establishment of cotton mills, the state was famous for the quality of its spun yarn and woven cotton cloth, produced with the help of handlooms. Eventually, this resulted in the blooming of the cotton trade between the state and other countries as well.

Coimbatore city is the hub for cotton spinning and weaving mills and other industries and is highly industrialized. It is the major center for cotton textile mills (about 90 mills) in Tamilnadu as well as South India. Most of the mills are concentrated within an area of 5-10 kms. radius, with their decentralized units located within an area of $20 \mathrm{kms}$. radius. Hence, the textile industry is the predominant industrial sector in the city and several diversified industries, particularly the engineering industry, have grown rapidly for the large-scale development of textile machinery.

The City Corporation reports that the Chettiyars form the largest caste group (largely consisting of traders, moneylenders and shopkeepers) and constitute about 15 per cent of total households. The next largest caste groups are the Gounders (largely farmers) and Scheduled Caste people (largely industrial workers), who constitute 12 per cent of households each. The Naidus (largely entrepreneurs) occupy third place, as they constitute about 11 per cent of total households. The other castes are not significant in terms of their numerical strength. However, at present, small groups of Kammavars, a sub-division of the Naidu caste, are the owners of most of the mills. In previous generations, most of them were landowners, mainly engaged in cotton cultivation. Later, they entered into cotton trading and finally launched ventures in yarn and cloth production. They ran about three-quarters of all mills, followed by the Chettiyars, who owned more than one-fifth of mills, whereas the Gounders were owners of about 5 per cent of mills. Besides the textile mills, the power loom units in and around the city also grew substantially. The owners of these units belonged to various castes: the majority caste group was the Mudaliars (61 per cent), a traditionally farming community, while the second majority group was the Devanga Chettiyars (18 per cent), who were conventionally handloom weavers.

The industrial history of Madurai city is closely associated with the textile mills and it is evident that this city was one of the big textile centers of South India until the 1990s. Next to Coimbatore, it took second place in terms of its concentration of cotton textile mills, which were famous even before the textile industries in India were modernized. It was mostly the Nattukottai Chettiyars, a popular trading and banking caste in Tamilnadu, who owned 
the mills and modernized them in an admirable way. Different types of production units have not proliferated in such numbers in Madurai compared to Coimbatore, hence it remains more or less a moderately industrialized city.

Unlike Coimbatore and Madurai, Tirunelveli District continues to be a dry tract of land except for the areas close to Thamirabarani River and the lands irrigated by its tributaries. Because of this, a barren stretch of land has remained uncultivated for decades. If there is cultivation in limited areas at all, it is because of seasonal rainfall. Except for beedi making (beedis are local cigarettes mostly consumed by the local labor force), which employs a large chunk of people in the district, there are no alternative employment opportunities in the district. Hence, it is relatively the least industrialized district. Nevertheless, within the district, Madura Fabrics (in the village of Vikramasingapuram) - established by a British industrialist in the early 20th century - has been one of the most popular textile mills in Tamilnadu. The South India Co-operative Spinning Mill was founded in 1958 near Tirunelveli city, but it became run down after four decades and was subsequently closed. Since 1970, four small spinning mills have been opened in the district despite the fact that cotton cultivation is less in the district than it was in Coimbatore and Madurai. There are, in addition, industries such as Sun Paper Mills Ltd., India Cement, several beedi companies, and cottage/small-scale industries. However, this area remains one of the least industrialized districts in Tamilnadu.

\section{INDUSTRIALIZATION AND THE EMERGENCE OF WORKING CLASS}

During the period of pre-industrialization in India caste was an extraordinarily intricate and relatively inflexible form of stratification. Initially, it tended to resist change, but since the 1960s, it has been undergoing significant changes rather than was experienced in its entire history. However, these changes are not fundamental, but largely peripheral. Nevertheless, in contemporary times industries are bringing people together from different castes. In terms of their interaction and interrelationships within the industries, they do not observe the traditional customs of their castes. Industrial organizations provide a work ethos in which the workers work together, dine together, and move freely with one another without reservation, presumably largely ignoring caste inhibitions during their interactions, though they do not suspend them completely. Consequently, the once-yawning gap between the high and low castes has become narrower. 
Because of the distinct changes that have taken place in the caste system, perceptible class distinctions have been emerging in India since the 1970s. Particularly in industrial towns and cities in contemporary India, the emergence of a labor class is quite evident, besides the formation of an agricultural labor class in rural areas. As regards to informal sector, Bhowmik (2009: 126-144) stresses the need to address the informal labour because of rapid changes taking place in the composition of workforce in India. However, the caste relations and caste loyalties of workers often hinder the formation of unity of the working class. Jayantanuja Bandyopadhyaya (2002) states that a poor 'upper' caste worker does not consider his poor 'lower' caste co-worker to be his equal, and usually the former refuses to have socio-cultural relations with the latter. Though the different caste workers join trade unions and participate in common strikes, most of them do so mainly for monetary or personal gain. They neither pay due attention to upholding their socio-cultural links which cut across caste barriers, nor do they attempt to strengthen their class unity in order to develop a class-consciousness.

Caste groups are not similar to class divisions. However, as Yogendra Singh (1977:137-154) points out, class incorporates some of the elements of caste. In support of this proposition, Sharma (1980:56-61) observes that "caste and class are inextricably tied together and the predominance of the values of caste suppress considerably the expression of class consciousness". It is thus evident that caste and class co-exist. However, caste neither permits the process of class crystallization nor does it retain its core elements. But, it tends to be resilient to changes and challenging situations in contemporary India and maintains its roots. Hence, it is at present relevant to study the probability of class crystallization amongst the industrial workers in India.

The labor class in Indian industries has a number of trade unions. Karl Marx (1973:149) was of the view that trade unions serve as ramparts for the workers in their struggle with their employers. For a class struggle to be maintained, class-consciousness amongst the workers is essential. When referring to this factor, Marx (1973:150) explains 'class in-itself' and 'class for-itself' as follows:

„Economic conditions had first transformed the mass of the people of a country into workers.... This mass is thus already a class as against capital, but not yet for itself. In the struggle, of which we have noted only a few phases, this mass becomes united, and constitutes itself as a class for itself. The interests it defends become class interests. But the struggle of class against class is a political struggle." 
Thus the objective understanding of workers about their position in relation to the position of capitalists and their subjective awareness of their freedom and problems coincides; their understanding of the existence of an unjustifiable authority and the power of the capitalists correspond to the main components of the Marxian theory of class. The combination of these two features causes class-consciousness amongst the workers. This consciousness enables the workers to meet their class interests through their action as a class. Therefore, Marx says, workers form a class provided they become organized and undertake class action.

However, in industrial organizations in India many of the union leaders have become selfish and look to make personal gains, besides consolidating the caste workers in their unions. On the other hand, a sizable number of workers are organized in unions for the purpose of safeguarding their jobs and personal interests rather than actively participating in class action to defend their class interests. Their activities tend to be focused on making personal gains instead of achieving wider goals. Moreover, a significant proportion of all workers want to be united in caste-oriented unions. Thus, the trade unions in India have partly been invaded by personal interests and the caste loyalty of the workers. This situation results in the emergence of in-group factions which make the unions weak and dormant. In support of this proposition, Mamkoottam (1977:167-190) points out that factionalism has taken deep roots in the labor unions in India. Workers largely think of union leaders, including executive committee members, as being selfish and as motivated by personal interests. They are often said to use their positions to secure promotions, good accommodation and jobs for relatives. Nevertheless, workers in certain unions - mostly communist unions - have a propensity to identify them with the labor class. Accordingly, analysis of class relations is necessary if they are to be compared with caste relations.

\section{METHODOLOGY}

In pursuance of this objective, two textile mills were selected from each of the sample districts of Tamilnadu, viz. Coimbatore (a highly-industrialized city), Madurai (a moderately-industrialized city) and Tirunelveli (the leastindustrialized city). Selection of these mills was based on the size of workforce and the level of industrialization in the districts where the sample mills were located. The main reason for selecting the cotton textile mills was that, as earlier described, they were the forerunners of India's transformation from an agrarian economy to an industrial economy. Their construction and operation 
laid the foundations for the development of many allied industries and service sectors; moreover, the mills were the sites in which the first labor unions were organized in India with the support of textile workers. Moreover, the time of their establishment and the type of ownership in the sample districts were different. Mills recruited workers from different cross sections of the population. These factors justify the selection of those mills in the study of the caste-class nexus in the working population.

A sample of 1008 workers was drawn from the total population of workers based on simple random sampling. Interviews were administered to collect mostly quantitative data from the sample workers. However, observation and case study methods were also used to collect qualitative data. In addition to this, informal discussions were held with all trade union leaders to collect qualitative information pertaining to their unions.

\section{PROFILE OF RESPONDENTS}

The age-wise distribution of sample workers shows that the overwhelming majority are adults aged between 30 and 50 (an average of 40 years). This represents the total working population in the sample mills. They were invariably literate, having at least studied until high school or higher secondary; having a high school education was a minimum qualification for their recruitment.

They belonged to various caste groups - more than fifteen - including the Christian and Islamic faith. The caste-wise distribution of workers was reflected in the caste composition of the population in the places where the sample mills were located. For instance, in the mills situated in Tirunelveli District, over one quarter of respondent workers belonged to the Pillai caste because they are widely distributed in the areas surrounding the mills. Similarly, the proportion of workers drawn from the Chenguntha Mudaliar caste (17 per cent), the Scheduled Caste (15 per cent) and the Nadar caste (11 per cent) roughly represented the caste composition of the population living in the areas surrounding the mills. In the sample mills situated in Madurai city, almost one quarter of the respondents were drawn from the Marava, a sub-caste of the Mukkulathor caste, because the areas in and around Madurai city were substantially populated by people of this sub-caste. A similar trend was reflected in the sample mills located in Coimbatore city where more or less one-third of workers were from the Gounder caste and close to one-fifth of them were from the Naidu caste; these two caste groups form the numerical majority in the city. 
Criteria such as education, occupation and income were used to classify the sample workers into two different class categories, viz. workers and operatives. The latter included jobbers (maistrys), fitters, oilers, and those operating electric motors and generators. All of them were technically qualified excluding the jobbers who became leaders of workers after rendering effective service as workers for several years. However, operatives belonged to the blue-collar category because they performed primarily manual work. This is perhaps the reason why, like the workers, they had membership in different labor unions. Nevertheless, unlike the workers, they were always keen on protecting the interests of management through the social relations of production for the reason that they were mostly establishment men, loyal to the management.

The jobbers, who had access to certain privileges and power, supervised and guided the workers and would sometimes, persuade management to suspend or dismiss errant workers. Nevertheless, sometimes they would represent the legitimate demands of the workers to the management. Though they had control over the workers, they remained part of workforce. Accordingly, the management did not treat them on a par with the middle management staff. This may be because the latter were technically-qualified individuals, whereas the former had acquired desirable skills mostly through experience. In spite of this, most of the time, their suggestions formed the basis of vital decisions that were taken by supervisors, their immediate leaders.

\section{WORKERS, UNION AND CLASS}

A trade union is a legitimate body for organizing workers and assisting them in giving voice to their rights, demands and grievances. They are expected to play an important role in maintaining cordial relations between management and labor and their main aim is to protect and advance the common interests of workers that arise through their work experience. Worker's common interests are often articulated in economic terms such as increases in wages, fringe benefits and incentives or bonuses. However, quite a few of the interests of workers are related to non-economic issues such as redressing grievances against management, working conditions, promotion, welfare measures and resistance to what workers might regard as unreasonable exercises of management authority.

In the sample mills, the workers organized several unions affiliated to various political parties. However, three unions [the Indian National Trade Union Congress affiliated to the Congress Party, the Centre for Indian Trade 
Unions affiliated to the Communist Party of India (Marxist), and the Textile Mill Workers' Association affiliated to Dravida Munnettra Kazhagam (DMK)] were incorporated in the analysis owing to the reason that all the other unions individually represented less than 10 per cent of the total population of the labor force. The INTUC comprised of the majority of the total workforce in the sample mills of Madurai and Tirunelveli, whereas one quarter of the total workforce in the sample mills in Coimbatore belonged to the CITU and rest of them were members of non-communist unions. However, mill management followed a strategy of recognizing the numerically dominant unions (mostly non-communist) and consulting them in times of labor problems, whereas it was neither willing to recognize nor liable to consult the minority unions (mostly communist) for the same reason.

When subscribing to unions, the workers in the sample mills also subscribed to their caste associations for membership. On several occasions, some politically-motivated union leaders were observed to be keen on influencing their caste workers from their own unions as well as other unions to subscribe to their caste associations and to eventually mobilize them to be active politically in order to gain political power. In Tamilnadu, particularly there are several caste-based political parties (G.Karunanithi, 2001: 89-100) whose goal is to consolidate caste members in order to achieve political power in general, and make representation to the Government to get their demands fulfilled in particular.

On many occasions, caste proved to be a significant factor in union elections. Union workers elect their caste men to positions of union leadership. Sometimes during union elections competition amongst the workers of majority castes became intense if they put their efforts into getting their caste members into leadership positions. In contrast to this, Murphy (1977:291321), who worked on caste, class and union in Chennai, Madurai, Coimbatore and Tirunelveli, discloses that though caste and communal ties were found among the workers of all the mills in these sample districts, they remained a poor substitute for effective union leadership and were in no way barriers to the development of class consciousness. Further, he states that neither caste nor community had an important role in complicating the system of labor organization - mainly in Coimbatore.

While exercising power, some union leaders in the sample mills took exceptional interest in solving the problems of their caste workers in the union, besides attending to the problems of other caste counterparts. They quite often motivated their caste workers to become members of their unions first and then members of their caste associations under the pretext of increasing union membership. Sometimes they persuaded caste workers 
in other unions to subscribe to their own caste associations. In the sample mills in Tirunelveli, nearly a majority of workers were members of their caste associations. A similar trend was identified with the workforce in the sampled mills in Madurai. In these mills, most of the workers were inclined to fostering caste relations rather than class unity. In a similar way, Lambert (1963) in an earlier study observes that workers are caste-minded and show no signs of transforming their attitudes and social relations. They view their jobs in the same way as they view their traditional caste occupations; i.e. they continued to assume a patron-client relationship. Lambert sees the consistency between traditional culture and industrialization. Chttopadhyaya and Sengupta (1969:1209-1216) demonstrate that caste continues to be a significant factor in structuring inter-personal relationships within factories. In the same way, Holmstorm (1978) states that caste is one of the influential factors in various industrial activities. Conversely, according to the findings of the present study, a great majority of the workers in the sample mills in Coimbatore had a propensity to prefer class relations to caste relations.

However, mill workers were apparently able to identify the class categories of other employees. For instance, the workers objectively understood their class position in relation to the class position of their immediate leaders, viz. masteries (foremen). They were equally aware of their subordinate positions in this regard, despite the fact that the latter had once also been workers. They subjectively understood that the masteries extract more work from them to satisfy management. This shows that occupation serves as a criterion for categorizing the industrial population into classes. In support of this proposition, D'Souza and Sethi (1972:35-47) considers occupation a useful objective index of social class. An overwhelming majority of workers in the sample mills indicated that the occupational position of employees was a decisive factor in classifying the mill population in terms of classes. However, it is obvious that occupation decides level of income, and that these factors are inseparable and interdependent. Therefore, this dyadic factor serves to be an important criterion in the class classification of the industrial population as well as the population of India.

Though the workers exhibited their caste loyalty on various occasions within and outside the mills, a large majority of them were aware of the importance of labor unity for solving internal problems. Due to this awareness they identified themselves with the labor class and developed class interest in order to get to know more about their rights and demands. Close to two-thirds of the sample workers in the selected mills raised awareness amongst their coworkers about their rights and demands. Over three quarters of them in the age group of 30-50 made efforts to raise awareness. Consequently, this initiated 
class-consciousness amongst them. Nevertheless, the proportion of workers who worked to raise awareness and develop class-consciousness amongst their co-workers increased along with the level of industrialization in the sample areas. It can therefore be understood that a high level of industrialization results in correspondingly a high level of unionization among workers and subsequently a high level of class-consciousness. However, in the sample mills there was a significant difference between workers in communist unions and non-communist unions in terms of raising awareness about their rights and demands amongst co-workers. The proportion of workers who did this in communist unions was relatively higher than those in non-communist unions.

Close to two-thirds of the sample workers used informal discussions as a means of developing a class-consciousness amongst their co-workers, whereas over one-third of them opted to do so at periodical union meetings. In a similar way, three quarters of them preferred informal discussions and one quarter of them resorted to formal union meetings to create awareness amongst their co-workers about their rights and demands. It is evident that informal discussions amongst workers, especially during tea breaks and lunchtime, played a crucial role in developing the workers' class-consciousness by raising awareness about rights and demands. However, the proportion of sample workers engaged in this activity varied significantly with respect to the level of industrialization in the sample areas; about one-third of workers in Tirunelveli, about 45 per cent of them in Madurai and about 60 per cent of them in Coimbatore.

In contemporary times, workers who are employed in organized sectors seem to have also become organized in their unions and started developing class-consciousness through their participation in union activities. Though they come from various caste groups and a mixed rural-urban background, they would like to be an organized force and are similar in several ways with respect to their occupations, income, rights, demands, problems and the like. As long as they continue to be workers in organized sectors they tend to exhibit their strength and power through their class action which is promoted by their class-consciousness. Nevertheless, the sample workers in the communist union outnumber their counterparts in the non-communist unions in terms of the development of class-consciousness. Moreover, the development of workers' class-consciousness depends on the duration of their work experience; e.g. workers with more than 10 years of work experience were more than twice as likely to report on the development of class-consciousness as their counterparts with less than 10 years of work experience, who felt it only moderately.

Workers elected apt candidates for union leadership because the former 
expected the latter to meet their needs and to attend to their work-related problems. The type of labor union was an influential factor in the workers' choice of candidates for union leadership. Among the sample respondents, close to three quarters of them in communist unions and nearly two-thirds of them in non-communist unions elected leaders, who were more concerned with labor welfare. This shows that, while electing union leaders, there was a significant difference between the communist union workers and their non-communist union counterparts. However, in this respect, caste plays an important role. For instance, union members of one caste preferred to elect a representative from their caste for leadership. On several occasions this was the practice in the sample mills in Tirunelveli and Madurai. On certain occasions this led to conflicts between two numerically-dominant caste groups in the same union. Nevertheless, this sort of intra-union conflict was rare in the sample mills in Coimbatore owing to this area's high level of industrialization and the orientation of workers to unionism. In support of this proposition, Ramasamy (1976:361-373) notes that a well-organized labor movement in Coimbatore created powerful new loyalties which make caste, kinship and other similar loyalties irrelevant in certain contexts. He attempts to establish this proposition with respect to workers' behavior within the union and the work environment as well. According to Ramasamy, various union activities do not run along caste lines. Similarly, Uma Ramasamy (1979:367-376) finds that caste is not a major influence on the social lives of industrial workers in an industrial suburb in Coimbatore. In a similar way, the present study reveals that within the sample mills in Coimbatore, the activities of a large workforce were not influenced by caste; instead, individuals identified mostly with the labor class, thought about class relations and took part in class actions to defend their class interests.

\section{DETERMINANTS OF CLASS CONSCIOUSNESS}

Labor unions have been a vital factor in the development of a workers' classconsciousness. It is explicit that the level of class-consciousness of those who actively participated in several union activities was appreciably higher than that of their counterparts whose participation in these activities was rather insignificant. However, overall participation in union activities was neither more nor less, but somewhat moderate. This situation almost corresponded to the level of workers' political participation in terms of attending party meetings, discussing party affairs with local leaders, canvassing during general elections and taking part in meetings organized by local political 
leaders. In other words, their level of union participation depended on their level of political participation. Sheth and Jain (1968:286-289) explain the relationship between the degree of politicization of workers and their level of commitment to unions. They disclose that the higher the political awareness of a worker, the greater his proclivity to union participation. Therefore, Sheth (1968: 5-18) sees trade union as an agent of political socialization and considers union activity to be political activity. The present study indicates a similar phenomenon: that the workers' level of class-consciousness depends on their level of union participation. In other words, the greater the level of union participation, the higher the level of class-consciousness. Comparative analysis of data about workers' levels of union participation and their level of class-consciousness proves this concomitant variation, thereby supporting the proposition that political participation is a prerequisite for participation in a union.

Workers were able to develop class-consciousness among their co-workers through informal discussions about work-related problems. In this regard, it is understood that the proportion of sample workers in Coimbatore (about 80 per cent) and in Madurai (about 70 per cent) is significantly higher than the proportion of their counterparts in Tirunelveli (about 45 per cent). It is clear that the level of industrialization in the sample areas accounts for the varying proportions of sample workers of those areas with respect to their engagement in developing class- consciousness. Sometimes members helped their union leaders to mobilize workers to represent work-related problems to management. In relation to this, the level of industrialization in the sample areas influenced the workers to mobilize through unions to represent their problems to management through their union leaders. About one quarter of workers from Tirunelveli, close to one-third from Madurai and more or less a majority from Coimbatore were engaged in this task. Moreover, a majority of sample workers from Coimbatore and approximately one-third of those from Madurai and Tirunelveli discussed various union-related problems. Sometimes they discussed those problems with their union leaders to arrive at a viable solution. More workers from Coimbatore than their counterparts from other sample areas had satisfactory union orientation, which increased the likelihood that they would discuss such problems amongst themselves and with their union leaders as well.

Since Coimbatore is a highly-industrialized area with age-old textile mills and other industries, the unionized workforce in the city was well aware of its rights and demands. Unlike this group, their counterparts in Madurai and Tirunelveli were only partially aware of their rights and demands. This is perhaps the reason why the proportion of sample workers in the former area 
was significantly higher than the proportion of their counterparts in the latter areas with respect to the tendency to oppose leaders' activities to suppress the workers' class interests. About half of the workers in communist unions opposed such activities, whereas about one-third of their counterparts in noncommunist unions exhibited a similar tendency. This proves that union type also influences the type of activity of workers. A similar trend is reflected in their propensity to oppose union leaders if the latter fail to attend to the problems of the former.

Sometime the management was indifferent to workers' demands. In order to overcome this situation, more or less a majority of sample workers in Coimbatore and Madurai registered their protests against management, whereas about one-third of their counterparts in Tirunelveli did the same. It is thus evident that the level of industrialization in these areas amplified the critical outlook of workers in relation to management attitudes to their demands. Over two-thirds of members of communist unions and about 50 per cent of members of non-communist unions denounced management's attitudes to workers' demands. This undoubtedly shows that the union type also influences workers' critical outlooks about management attitudes. Likewise, workers took part in strikes against management if their demands remained unfulfilled. Approximately two-thirds of respondents in Coimbatore and Madurai participated in strikes against management, whereas onethird of their counterparts in Tirunelveli did so. This significant variation in participation in strikes strongly highlights the tendency of workers in highly as well as moderately-industrialized areas to engage in union activities to get their demands materialized compared to their counterparts in the least industrialized areas.

In the sample mills at Tirunelveli and Madurai, the management predominantly recognized numerically well-supported unions and did not recognize smaller unions, irrespective of their affiliation with political parties. Moreover, recognition of a union was chiefly dependent on the loyalty of union leaders to the management. This sort of practice turned the minority unions against the establishment. Ultimately, this led to a split between unions into two hostile camps within the mills. On certain occasions this resulted in inter-union conflicts, which shook workers' faith in the unions itself. Sometimes, the rival unions clashed, obstructing each other's normal union activities. Altogether, about three quarters of workers in the sample mills were of the opinion that, over the years, the management had followed a policy of 'divide and rule'. The hidden agenda was that management always wanted to safeguard its profits gained through the sweat of workers, and to maintain hostility between recognized and unrecognized unions. 
The multi-unions in the sample mills in Tirunelveli and Madurai became dichotomous. The leaders of recognized unions became tools of management, mostly for personal gain, and hence they barely attempted to develop class-consciousness amongst the workers. On the other hand, the leaders of unrecognized unions opposed management's anti-labor attitudes and activities. Whenever serious labor problems remained unsolved, they caused their union members to participate in strikes against management. In turn, management attempted to break the strikes strategically with the support of recognized unions. On several occasions these crucial situations resulted in conflicts between the communist and non-communist unions and led to the disintegration of the workforce. Moreover, it is inferred from discussions that the management was a decisive and divisive force with respect to workers and their unions.

\section{CONCLUSION}

In contemporary Indian society, caste remains a resilient system that exists for the purpose of ensuring sustenance. It continues to maintain its core elements to withstand the challenges posed by modern forces. This is perhaps the reason why the working class in the sampled mills has not yet crystallized in the way that caste has. Moreover, the phenomenon of multiunionism appears in the form of workers' political forums that are influenced by the caste nexus to an appreciable extent. Union leaders appear to have assumed certain characteristic features of the leaders of caste associations and after sometime they will become leaders of political parties. In this transition, union leaders tend to unite their caste workers and safeguard their interests using the pretext of organizing the workers to strengthen their unions. Caste makes perceptible in-roads into the activities of labor unions, making them dormant bodies and preventing the development of class unity and classconsciousness. Nevertheless, mostly communist union-affiliated workers have a tendency to identify them with the labor class and safeguard their class interests through class action.

The aim of this paper is to describe to what extent the labor unions facilitate the development of workers' class-consciousness and foster the process of the crystallization of their class in the sampled textile mills selected from three differently-industrialized districts of Tamilnadu. An interview process, supplemented by observation and case study, was administered to collect data from a sample of 1008 workers selected from the sample mills based on simple random sampling method. 
Largely, the sample workers were young and literate. A majority of workers had an average of 15 years of work experience. Their distribution, caste-wise, depended on the caste-composition of the population in the areas surrounding the sample mills. The labor class includes manual workers as well as operatives. Unlike workers, operatives demonstrated their loyalty to management by protecting their interests within the social relations of production.

There were several trade unions that were affiliated with various national and regional political parties. Management tended to recognize the bestsupported unions (mostly non-communist unions), to consult with them and to seek their support during labor problems. On the other hand, the management neither recognized the less well-supported unions (mostly communist unions) nor consulted with them to obtain their support in solving problems with labor. This policy of 'divide and rule' split the workers into two opposing groups: communist union workers and non-communist union workers. Thus, by creating inter-union conflict between the different unions, management attempted to smash the unity of labor and their movements. Moreover, some of the non-communist union leaders were also partly responsible for this problem. They attempted to persuade caste workers to subscribe to their caste associations for membership, irrespective of their union affiliations. Surprisingly, a majority of respondent workers happened to be members of caste associations which have been influential in union activities over years. It is concluded that union leaders were keen on consolidating their caste workers for political reasons and personal gains as well.

In the sample mills, a majority of workers could identify the different class positions of employees. They objectively understood their class position in relation to that of other class categories of employees who were above them in the occupational hierarchy. They were also aware of their subordinate position and their being subject to exploitation by management. This awareness resulted in the formation of class interests among the workers, and, subsequently, the initiation of class action to defend such interests. This is perhaps the reason that a great majority of respondents considered occupation to be an important criterion for classifying the industrial population in India into class categories.

Workers were aware of the importance of labor unity and labor power at times of problems at the mills. This awareness united them together in a labor class and made them identify with one another. This class identity developed their class-consciousness, which in turn facilitated class action against the management to defend and represent class interests. In terms of class action, it was mostly communist union workers who raised awareness amongst 
their co-workers about their rights and demands. It was made explicit that the awareness of workers in highly-industrialized Coimbatore, moderatelyindustrialized Madurai and least industrialized Tirunelveli differed significantly. More workers in communist unions raised awareness through informal discussion and union meetings than their counterparts in the noncommunist unions. However, in doing so, a great majority of them followed the path of informal discussion. The development of the class-consciousness of workers in Coimbatore and Madurai varied from that of their counterparts in Tirunelveli, in accordance with the different levels of industrialization of these places. Additionally, the development of class-consciousness amongst the workers in communist unions was greater than that of their counterparts in non-communist unions partly because of the 'divide and rule' policy of management. During most of the non-communist union activities, in one way or another, caste continued to be an influential factor and, correspondingly, workers in these unions became part of sectional and divisive forces. Unlike them, workers in communist unions did not entertain caste relations.

In spite of all these drawbacks, workers exhibited their class interests through various union activities, including strikes. However, such activities did not ultimately result in class crystallization because there was already a clear division of castes within the workforce. It is thus evident that caste relations, multi-unionism, the vested interests of the union leaders, the 'divide and rule' policy of management and inter and intra-union conflicts were the major factors that prevented the advancement of a workers' classconsciousness and the corresponding class action which would safeguard workers' class interests. Hence, a host of factors prevented the emergence of a favorable environment for class crystallization in the sample mills.

Nevertheless, the forces of contemporary times may likely to create a situation in which caste will lose importance in industrial organizations elsewhere in India. Consequently, class relations may likely to integrate the workers, irrespective of their caste, region and religion. The task of orienting the workers along class lines through periodical meetings, informal discussions and personal contacts is a viable strategy for developing class-consciousness. Moreover, the role of labor unions in developing a self-conscious labor class is crucial to this endeavor. However, management may likely to suppress the development of such a self-conscious labor class through creating a divisive and decisive strategy to defend its own interests. This strategy may be designed in such a way to pamper the leaders of majority unions and to encourage them to disregard the major interests of the workforce, and moreover, to alienate the leaders of minority unions and set them in conflict with the former. In sum, this may cause workers to lose their faith in union leaders, and then, 
ultimately, in unionism itself. In such a situation, the likelihood of class crystallization seems to be outside the reach of industrial workers in India.

\section{REFERENCES}

Bandyopadhyaya, Jayantanuja (2002), "Class struggle and Caste Oppression: Integral Strategy of the Left", The Marxist Vol. 18, No. 3 \& 4.

Bhowmik, Sharit K (2009), "India- Labour Sociology Searching for a Direction”, Work and Occupations Vol.36, No 1, pp.126-144.

Chattopaddhyaya, G and Sengupta, A.K (1969), "Growth of a Disciplined Labour Force: a Case Study of Social Impediments", Economic and Political Weekly Vol.4, No. 28, 29 \& 30, pp.1209-1216.

D’Souza, V.S and Sethi, R.M (1972) "Social class and occupational prestige in India: A case study", Sociological Bulletin Vol.21, No.1, pp.35-47.

Holmstrom, Mark (1978), South Indian Factory Workers: Their Life and their World, Bombay, Allied.

Karunanithi, G (2001), "Political Reincarnation of Caste Groups in Tamilnadu: Some Lessons for Democratic Parties," in: G. Karunanithi and R. Balachander, ed., Literature and Society-Twentieth Century Tamilnadu, Tirunelveli, Manonmaniam Sundaranar University Publication Division, pp.89-100.

Lambert, R. D (1963), Workers, Factories and Social Change in India, Princeton, NJ, Princeton University Press.

Mamkoottam, K (1977), "Factionalism and Power in Trade Unions: A Case Study", Indian Journal of Industrial Relations Vol.13, No.2, pp.167-190.

Marx, K (1973), The Poverty of Philosophy, Moscow, Progress Publishers.

Murphy, E.D (1977), "Class and Community in India: The Madras Labour Union, 1918-1921", The Indian Economics and Social History Review Vol. 14, pp.291321.

Ramasamy, E.A (1976), "Trade Unions and Caste in South India”, Modern Asian Studies Vol. 10, No.3, pp.361-373.

Ramasamy, Uma (1979), "Tradition and Change among Industrial Workers", Economic and Political Weekly Vol.14, No.7\&8, pp. 367-376.

Sharma, K.L (1980), Essays in Social Stratification, Jaipur, Rawat.

Sheth, N.R and Jain, S.P (1968), "Workers, Leaders and Politics: A Case Study", Indian Journal of Industrial Relations Vol.3, No.3, pp.286-289.

Sheth, N.R (1968), "Trade Unions in India: A Sociological Approach", Sociological Bulletin Vol.17, No.1, pp.5-18.

Singh, Yogendra (1977), "Changing pattern of Social Stratification" in: M.N.Srinivas, S.Seshaiah and V.S. Parthasarathy, eds., Dimensions of Social Change, Bombay, Allied, pp.137-154. 
